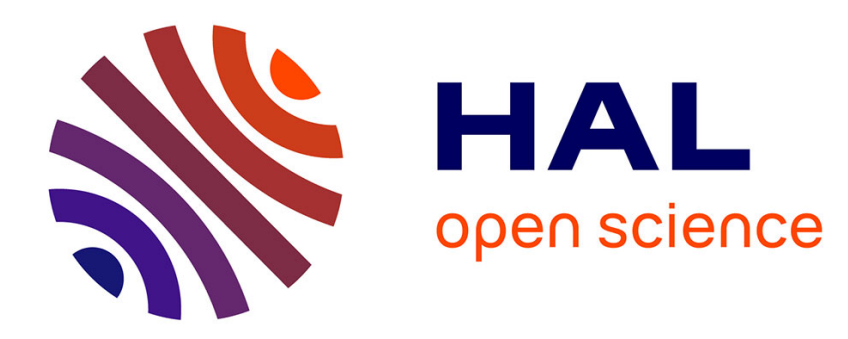

\title{
Heat shock protein expression pattern (HSP70) in the hydrothermal vent mussel
}

\author{
Pruski A.M., R. Dixon D.
}

\section{To cite this version:}

Pruski A.M., R. Dixon D.. Heat shock protein expression pattern (HSP70) in the hydrothermal vent mussel. Marine Environmental Research, 2007, 64 (2), pp.209. 10.1016/j.marenvres.2007.01.003 . hal-00501905

\section{HAL Id: hal-00501905 \\ https://hal.science/hal-00501905}

Submitted on 13 Jul 2010

HAL is a multi-disciplinary open access archive for the deposit and dissemination of scientific research documents, whether they are published or not. The documents may come from teaching and research institutions in France or abroad, or from public or private research centers.
L'archive ouverte pluridisciplinaire HAL, est destinée au dépôt et à la diffusion de documents scientifiques de niveau recherche, publiés ou non, émanant des établissements d'enseignement et de recherche français ou étrangers, des laboratoires publics ou privés. 


\section{Accepted Manuscript}

Heat shock protein expression pattern (HSP70) in the hydrothermal vent mussel

Bathymodiolus azoricus

Pruski A.M., Dixon D. R.

PII:

S0141-1136(07)00017-7

DOI:

10.1016/j.marenvres.2007.01.003

Reference:

MERE 3096

To appear in:

Marine Environmental Research

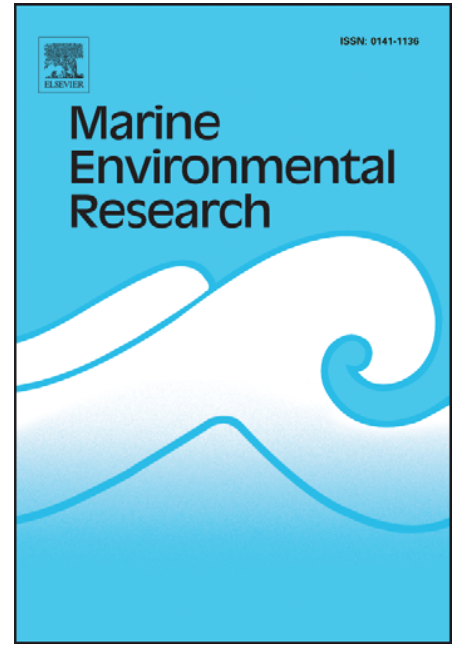

Received Date: $\quad 31$ August 2006

Revised Date: $\quad 10$ January 2007

Accepted Date: $\quad 11$ January 2007

Please cite this article as: A.M., P., R., D.D., Heat shock protein expression pattern (HSP70) in the hydrothermal vent mussel Bathymodiolus azoricus, Marine Environmental Research (2007), doi: 10.1016/j.marenvres. 2007.01.003

This is a PDF file of an unedited manuscript that has been accepted for publication. As a service to our customers we are providing this early version of the manuscript. The manuscript will undergo copyediting, typesetting, and review of the resulting proof before it is published in its final form. Please note that during the production process errors may be discovered which could affect the content, and all legal disclaimers that apply to the journal pertain. 


\section{Heat shock protein expression pattern (HSP70) in the hydrothermal vent mussel Bathymodiolus azoricus}

\section{Pruski A.M.*\# and Dixon D. R. \#\#}

National Oceanography Centre, University of Southampton, Waterfront Campus, Southampton SO14 3ZH, United Kingdom

* Corresponding author: audrey.pruski@obs-banyuls.fr , Fax : 00334688873 95, Laboratoire d'Océanographie Biologique de Banyuls, UMR7621, BP44, F-66650 Banyuls-sur-Mer, France

\# Present address: Université Pierre et Marie Curie, Laboratoire d'Océanographie Biologique de Banyuls, UMR7621, BP44, F-66650 Banyuls-sur-Mer, France

\#\# Present address: Marine Biological Association, Citadel Hill, Plymouth PL1 2PB, United Kingdom

\section{Abstract:}

We previously reported evidence of increased levels of DNA damage in the hydrothermal mussel Bathymodiolus azoricus, which suggested that the species was not fully resistant to the natural toxicity of its deep-sea vent environment. In the present study, HSP70 was used as a biomarker of sub-cellular stress. Differences in HSP70 expression pattern were observed between vent sites, typified by different depths/ toxicity profiles, and between different mussel tissue types. A comparison of specimens collected by ROV (Remote Operated Vehicle) and acoustically-operated cages showed that less stress (as indicated by changes in HSP70 levels) was induced by the faster cage recovery method. Therefore alternatives to ROV collection should be considered when planning experiments involving live deep sea organisms. Significantly, a positive correlation was 
found between the levels of DNA strand breakage, as measured using the Comet assay, and HSP70 expression pattern; evidence was also obtained for the constitutive expression of at least one HSP isoform which was located within the cell nucleus.

Keywords: Bathymodiolus azoricus; Mussels; Hydrothermal vents; Heat shock response; HSP70; Western blot; DNA damage. 


\section{1- Introduction}

Evidence of an age-related increase in DNA strand breakage in the Mid-Atlantic Ridge vent mussel, Bathymodiolus azoricus, suggests that this and other hydrothermal species are not fully resistant to the damaging effects of their hostile deep-sea environment (Pruski \& Dixon, 2003). However, a major complicating factor when attempting to perform toxicological studies on deepsea species in the laboratory has been exposure to decompression stress at the time of collection, which can lead to increased levels of DNA damage (Pruski \& Dixon, 2003), attributable to enzyme mediated damage to cells, and irreversible protein denaturation as shown in the abyssal fish Coryphaenoides acrolepis (Mosholder, Josephson, \& Phleger 1979).

In order to obtain a greater understanding of the effects of decompression stress, we used Western blot analysis to quantify the relative amounts of the stress protein HSP70 in B. azoricus immediately after recovery and during subsequent laboratory acclimation. Stress or heat shock proteins (HSP) are a large group of highly conserved proteins, which are rapidly synthesized in response to stress in all organisms, from bacteria to humans. The most intensively studied of these is the multigenic HSP70 family, which contains a number of different isoforms of approximately 70 $\mathrm{kDa}$ molecular weight, which includes the heat-inducible HSP70 and constitutively expressed HSC70. In addition to thermal stress, the synthesis of these proteins has been shown to be induced by a wide range of proteotoxic stressors such as heavy metals, ethanol, TBT (tributyltin), PCB (polychlorobiphenyl), $\mathrm{H}_{2} \mathrm{O}_{2}$, SDS (sodium dodecyl sulphate), lindane, diazinin, amino acids analogues, and physiological stress such as anoxia, caloric restriction and oxidative stress (De Maio, 1995; Dyer et al., 1993; Sanders, 1993). In the last decade, field and laboratory studies performed on a variety of marine invertebrates have validated the use of HSP70 as a general stress biomarker (Bradley, Olsson, Brown, \& Tedengren, 1998; Radlowska \& Pempkowiak, 2002; Sanders, 1993), although recent evidence shows that HSP70 also plays an important role in acquired tolerance (Tedengren, Olsson, Reimer, Brown, \& Bradley, 1999). 
At the molecular level, HSP70 proteins are involved in the folding and assembly of native proteins

(Fink, 1999). Under stress conditions, apart from this cytosolic function, they have been shown to migrate into the cell nucleus where they act to repair or protect the nuclear proteins and to minimise protein aggregation which would otherwise lead to genetic damage (Bensaude, Pinto, Dubois, Van Trung, \& Morange, 1990; Ohtsuka \& Hata, 2000). HSP70 proteins are also known to facilitate the transport of damaged proteins to the lysosomes, for subsequent enzyme-mediated breakdown (Wickner, Maurizi, \& Gottesman, 1999), while suppressing apoptosis pathways; thus providing cells with increased time to effect repair (Verbeke, Fonager, Clark, \& Rattan, 2001). Of relevance to our interest in DNA damage (Pruski \& Dixon, 2003) is the recognised involvement of HSP70 in the process of base excision repair (Bellmann, Wenz, Radons, Burkart, Kleeman, \& Kolb, 1995; Burkart et al., 2000; Kenny et al., 2001).

In this study, we analysed the expression pattern of HSP70 in specimens of the Atlantic vent mussel B. azoricus collected from three active vent sites on the Mid-Atlantic Ridge, south-west of the Azores archipelago; sites which are characterised by different depth and contaminant load characteristics - note, vents above 1000 metres depth $(<100$ bar pressure) are typified by reduced contaminant concentrations, due to the phenomenon of phase separation (Charlou et al. 2000). In addition, we investigated the sub-cellular localisation of these proteins under stressed and 'low stress' conditions. Given that all the vent mussels we examined were subjected to some form of collection stress, we used the term low stress to mean without the additional thermal stress that the stressed group received.

\section{Materials and methods}

\subsection{Animal collection}

Large adult specimens ( $88 \pm 10 \mathrm{~mm}$ shell length) of $B$. azoricus were collected from three different vent sites south west of the Azores arquipelago: Menez Gwen $\left(37^{\circ} 51^{\prime} \mathrm{N}, 32^{\circ} 31^{\prime} \mathrm{W}, 840 \mathrm{~m}\right.$ depth),

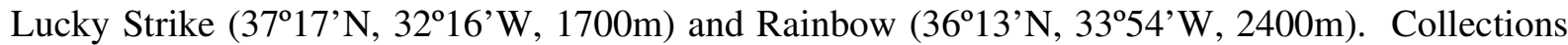


were made using either the French Victor 6000 ROV (Remote Operated Vehicle, IFREMER), during the EU-funded ATOS cruise (Sarradin et al., 2001), or retrievable cages designed as part of the EU-funded VENTOX programme (Dixon et al., 2001). Immediately after animal collection, the gills and mantle tissues were excised, on ice, and stored for later analysis in liquid nitrogen. At the same time, 8 specimens, collected using the ROV from the Menez Gwen site, were immersed in warm water, $\sim 28^{\circ} \mathrm{C}$ for $4 \mathrm{~h}$, prior to excising their tissues. Previous work having shown that mussels from the Menez Gwen site had the best post-collection survival potential, due to the shallower depth (Pruski \& Dixon, 2003).

Some of the Menez Gwen vent mussels we collected with the retrievable cages ( 200) were kept in a containerised cold room at the Department of Oceanography and Fish Biology, University of the Azores (Horta, Faial). These animals were kept in clean aerated sea water, at $7-8^{\circ} \mathrm{C}$, their natural ambient temperature (Sarradin P.M., unpublished), without food for 1 week. Since B. azoricus depends largely on endosymbiotic bacteria for its nutrition (Trask \& Van Dover, 1999), this meant withholding access to hydrogen sulphide and methane (Fiala-Médioni et al., 2002). It should be noted that mussels kept in the presence of these two gases showed higher levels of DNA damage (as DNA strand breakage measured using the Comet assay) than those kept without any 'food supplement' (Dixon, Pruski \& Dixon, 2004).

Specimens of the edible mussel Mytilus edulis, collected from Hill Head, Hampshire, UK, a relatively uncontaminated coastal locality, based on DNA strand breakage levels (Pruski \& Dixon 2003), were transported by ship to the mid Atlantic in aerated aquaria at $15^{\circ} \mathrm{C}$, during which time they were fed a proprietary fish food (Liquifry; Interpet, Dorking). In order to induce a HSP70 response 8 animals were exposed to elevated temperature, $28^{\circ} \mathrm{C}$ for $4 \mathrm{~h}$, similar to what we did with B. azoricus, while a control group was maintained in an aquarium at $15^{\circ} \mathrm{C}$, their natural ambient temperature. Another group of edible mussels was exposed to cadmium $\left(0.2 \mathrm{mg} \mathrm{l}^{-1}\right.$ of $\left.\mathrm{CdCl}_{2}\right)$ at a density of four mussels per tank containing 10 litres of ASW (artificial sea water), (Pruski \& Dixon, 
2002). This non lethal concentration of cadmium has already been shown to induce HSP70 expression in bivalves (Radlowska \& Pempkowiak, 2002), and our own previous work showed that this dose significantly reduces both DNA repair efficiency and apoptosis levels in M. edulis (Pruski \& Dixon, 2002).

\subsection{Preparation of tissue samples}

Frozen tissue samples (300-400mg) were homogenised on ice in $1 \mathrm{ml}$ of protein extraction buffer (10mM Tris $\mathrm{HCl}, 0.5 \mathrm{mM}$ sucrose, $0.15 \mathrm{mM} \mathrm{KCl}, \mathrm{pH} 7.6)$ supplemented with complete protease inhibitor cocktail (Roche). The homogenates were sonicated for 2 minutes and then centrifuged $\left(6000 \mathrm{~g}, 10\right.$ minutes, $\left.4^{\circ} \mathrm{C}\right)$. A subset of supernatants was used for protein determination. Total protein content was determined with the Bio-Rad protein assay kit, using bovine plasma albumin as a standard. The remainder was diluted in extraction buffer, mixed 3:1 (v:v) with $4 \mathrm{X}$ loading buffer (0.5M Tris $\mathrm{HCl} \mathrm{pH} 6.8,4 \% \mathrm{SDS}, 40 \%$ glycerol, 4\% 2 ß-mercaptoethanol, $0.04 \%$ bromophenol blue), boiled for $5 \mathrm{~min}$, and then stored at $-20^{\circ} \mathrm{C}$ prior to immunochemical analysis (final concentration $800 \mu \mathrm{g}$ of protein per $\mathrm{ml})$.

\subsection{Sub cellular fractionation of proteins}

For this we followed the protocol described by Sim \& Chow (1999), but to compensate for the marine nature of the study species, the osmolarity of the lysis buffer was adjusted to $3.3 \%$ with $\mathrm{NaCl}$ (Sigma). Total protein lysates were prepared from gill tissue $(\sim 0.3 \mathrm{~g}$ of frozen tissue/ml buffer) using non-denaturing lysis buffer $(100 \mathrm{mM}$ Tris- $\mathrm{HCl}, 150 \mathrm{mM} \mathrm{NaCl}, 1 \%$ sodium deoxycholate, $1 \%$ Triton $\mathrm{X}-100 \mathrm{pH} 7.5$ ) and complete protease inhibitor cocktail (Roche). Lysates were then sonicated for $2 \mathrm{~min}$, to facilitate breakage of cells and organelles, followed by centrifugation at $3000 \mathrm{rpm}$ for 10 minutes.

Samples, approximating $0.3 \mathrm{~g}$ of frozen tissue, were rinsed twice in PBS, $\mathrm{pH}$ 7.4. Proteins were then extracted for 15 minutes on ice, in $1 \mathrm{ml}$ of lysis buffer containing $10 \mathrm{mM}$ Tris- $\mathrm{HCl}, 150 \mathrm{mM}$ 
$\mathrm{NaCl}, 2 \mathrm{mM} \mathrm{MgCl}_{2}, 3 \mathrm{mM} \mathrm{CaCl}, 3 \mathrm{mM}$ dithiothreitol, 0.02\% IGEPAL CA-630 (pH 7.5) and complete protease inhibitor cocktail (Roche). The extract was then centrifuged at $2000 \mathrm{rpm}$ for 10 minutes. The pellet (P1) was resuspended in $1 \mathrm{ml}$ of buffer $(10 \mathrm{mM}$ Tris- $\mathrm{HCl}, 10 \mathrm{mM} \mathrm{NaCl}, 3 \mathrm{mM}$ $\mathrm{MgCl}_{2}, 5 \mathrm{mM}$ EDTA and protease inhibitor cocktail, $\left.\mathrm{pH} 7.4\right)$ and was centrifuged at $2000 \mathrm{rpm}$ for 10 minutes, and the supernatant (S2) that contained proteins from the nuclear fraction was harvested. The initial supernatant (S1) was ultracentrifuged at $100000 \mathrm{~g}$ at $4^{\circ} \mathrm{C}$ for $1 \mathrm{~h}$. The resulting pellet (P3) and supernatant (S3) were saved. P3 containing the microsomal fraction was treated in the same way as $\mathrm{P} 1$. S3 representing the cytosolic proteins was brought to $1 \%$ sodium deoxycholate and 1\% Triton X-100. Aliquots of the nuclear, cytosolic and microsomal fractions were saved for protein quantification. All these procedural steps were carried out on ice. Finally, the extracts were diluted with suspension buffer before the addition of loading buffer, and were boiled for $5 \mathrm{~min}$ (final concentration $800 \mu \mathrm{g}$ of protein per $\mathrm{ml}$ ).

\subsection{Western blot analysis of heat shock proteins}

The polyclonal antiserum used as a probe in the Western blotting experiments was raised against recombinant human HSP70 and detected a $70 \mathrm{kDa}$ protein band. This corresponded to the apparent molecular mass of HSP70 as detected on SDS-PAGE (sodium dodecyl sulphate polyacrylamide gel electrophoresis) immunoblots previously performed on samples from several invertebrate species (StressGen Biotechnologies Corp.). This antibody is claimed by the manufacturer to be specific for the inducible form of HSP70 (HSP72), while not cross-reacting with the constitutive HSC70 (HSP73) or DnaK (StressGen Biotechnologies Corp.). Although their test species range from humans to cnidaria,, this property has not been tested directly on mussels, and this should be borne in mind when considering these research findings.

Equal amounts of protein $(12 \mu \mathrm{g})$ from each tissue was separated by SDS-PAGE on $0.75 \mathrm{~mm}$ thick, 7.5\% acrylamide gels according to Laemmli (1970) using the Bio-Rad Mini-PROTEAN 3 Cell. Following separation, the proteins were electrophoretically transferred onto nitrocellulose 


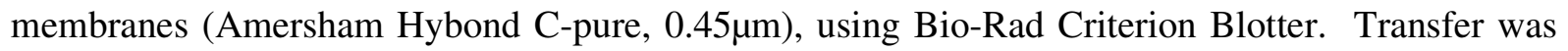
carried out at $400 \mathrm{~mA}$ for 90 minutes in a transfer buffer containing $25 \mathrm{mM}$ of Tris- $\mathrm{HCl} \mathrm{pH} 8.3$, $192 \mathrm{mM}$ glycine and 20\% isopropanol. Western blotting was then performed using the Amplified Alkaline Phosphatase Immun-Blot Assay kit, according to the manufacturer's instructions (BioRad). The membrane was blocked for $2 \mathrm{~h}$ with 5\% milk powder in TBS (Tris buffer saline:20mM Tris and $500 \mathrm{mM} \mathrm{NaCl}, \mathrm{pH} 7.5$ ) and subsequently probed with a polyclonal HSP70 primary antibody (SPA-812 rabbit HSP72 antibody from StressGen Biotechnologies Corp., dilution 1/20000) for $1 \mathrm{~h}$ at room temperature. The blot was then further incubated for $1 \mathrm{~h}$ with biotinylated goat anti-rabbit IgG. The presence of the primary antibody was detected using a $1 \mathrm{~h}$ incubation in streptavidin-biotinylated alkaline phosphatase complex. After incubation, each membrane was washed 3 times in TTBS (TBS/0.05\% Tween 20). Bands on the membranes were visualized with colour development solution and quantified by densitometry using a gel scanning system (Bio-Rad Gel Doc 2000). Negative controls without the primary antibody gave no evidence of bands. The molecular sizes of the resolved bands were determined by comparing their mobilities with those of prestained precision protein standards (Bio-Rad). On each gel, $15 \mu \mathrm{l}$ of the same gill extract of $M$. edulis was loaded as an internal standard. For quantification purposes, each band recorded from the B. azoricus samples was expressed as a percentage of the single band recorded for the M. edulis standard. Differences between the mean intensities of protein bands were tested using the nonparametric Wilcoxon-Mann \& Whitney U-test $(P \bullet 0.05)$. Correlation was tested using the nonparametric Spearman rank-order coefficient analysis $(P<0.05)$.

\section{Results}

\subsection{Levels of HSP70 in Mytilus edulis}

A single immunoreactive band $(\mathrm{Mr} \sim 70 \mathrm{kDa})$ was recorded from both the gill and mantle tissues of control M. edulis (a representative Western blot is shown in Fig. 1). The intensity of this band increased considerably after the mussels had been exposed to heat $\left(28^{\circ} \mathrm{C}\right.$ for $\left.4 \mathrm{~h}\right)$ or cadmium $(0.2 \mathrm{mg}$ $1^{-1}$ for 4 days). Another band with a higher molecular weight ( $\mathrm{Mr} \sim 77 \mathrm{kDa}$ ) was observed in some 
samples from control mussels, but not all (data not shown), and was abundant in the case of stressed mussels. This confirmed that the primary antibody used for this study was able to detect what may be a mixture of constitutive and inducible isoforms of putative HSP70 in a closely related bivalve species, which belongs to the same molluscan family (Mytilidae) as B. azoricus.

\subsection{Levels of HSP70 in vent mussels from the three sites varying in depth and contaminant load}

For $B$. azoricus, the antibody cross-reacted with three protein bands on the membranes, respectively 64, 71 and $76 \mathrm{kDa}$ (Fig. 2); two of which appeared to be inducible. Results of the densitometric analysis conducted on the Western blots are shown in Figure 3. The $71 \mathrm{kDa}$ protein was detected in the mantle and gill tissues of vent mussels collected from all three sites. Its relative abundance was similar in both gill and mantle (Fig. 3). We found no significant differences in the relative intensities of this HSP70 band amongst samples collected from Menez Gwen, Lucky Strike and Rainbow, despite their different depths and putative contaminant loads, which supports the hypothesis that this protein is constitutively expressed.

A light weight protein, corresponding to $64 \mathrm{kDa}$, was detected by the HSP72 antibody in nearly every gill sample from B. azoricus (Fig. 2). However, the relative intensity of this $64 \mathrm{kDa}$ band varied considerably between samples, with no obvious site-related trend, i.e. in terms of depth or contaminant load. A third protein with a molecular mass of $76 \mathrm{kDa}$ was also detected in some gill extracts ( $20 \%$ of the samples), but was not recorded in mussels from the shallowest $(840 \mathrm{~m})$ Menez Gwen site, where the chemical conditions are known to be less hostile due to the phenomenon of subsurface phase separation (Charlou et al, 2000; Desbruyères et al., 2001).

\subsection{Effects of collection and post-collection acclimation on the expression of HSP70 in $\mathrm{B}$. azoricus} gill tissue

A representative Western blot showing the HSP70 responses of vent mussels immediately after collection and after 7 days acclimation in the laboratory at 1 bar pressure is shown in Figure 4 . In 
keeping with its proposed inducible properties, the levels of the $64 \mathrm{kDa}$ protein band were found to be significantly lower in the aquarium acclimated mussels compared to freshly ROV-collected animals (Wilcoxon-Mann \& Whitney U-test, $P=0,021, \mathrm{~N}=8$ ), while the relative intensity of the 71 $\mathrm{kDa}$ band was relatively constant between treatments, which was consistent with its proposed constitutive nature. This result provides support for the $64 \mathrm{kDa}$ protein being inducible in $B$. azoricus. In support of these conclusions, Figure 5 shows the intensity of the 64 and $71 \mathrm{kDa}$ bands for various treatments corresponding to different levels of stress. As expected, the relative intensity of the $64 \mathrm{kDa}$ isoform was slightly higher in ROV collected mussels that had been exposed to heat shock compared to those that had been simply ROV collected. This shows that the $64 \mathrm{kDa}$ isoform was synthesized de novo in response to the cellular stress induced by an increase in temperature, from 7 to $28^{\circ} \mathrm{C}$. Interestingly, for mussels collected with the retrievable cages, the $64 \mathrm{kDa}$ isoform values were lower than for the ROV-collected mussels (Wilcoxon-Mann \& Whitney U-test, $P<0.05, \mathrm{~N}=8$ ). This supported our previous findings, based on baseline DNA damage levels, which showed that the retrievable cages represent a less stressful recovery method for vent mussel compared to ROV collection (Dixon et al., 2004). Significantly, no increase in HSP70 isoforms was observed in Menez Gwen mussels that had been kept for 1 week in the laboratory aquarium at 1 bar pressure, which confirmed their stable condition. Note, vent mussels from Menez Gwen vent site were subsequently kept in the laboratory at 1 bar pressure for more than 12 months on a diet of sulphide and methane (P. Dando, pers. com.).

\subsection{Sub cellular localisation of HSP70 in Bathymodiolus azoricus}

The sub cellular localisation of HSP70 isoforms was investigated in gills of mussels from Menez Gwen immediately after ROV collection (i.e. stressed during the collection process) and after 1 week's acclimation to aquarium conditions, without food (Fig. 6). The constitutive $71 \mathrm{kDa}$ band was present in the three sub fractions (cytosolic, nuclear and microsomal) derived from both the stressed and unstressed mussels, while the $64 \mathrm{kDa}$ was only present in the cytosolic fractions. 
3.5. Relationship between the levels of HSP70 and DNA strand breakage in gills of Bathymodiolus azoricus

DNA damage was evaluated with the single cell gel electrophoresis (Comet) assay on the same individuals (see Pruski and Dixon, 2003 for a discussion on DNA strand-breakage in B. azoricus). Despite the high inter-individual variability and low $\mathrm{N}$ value (10), there was evidence suggesting a positive correlation between the levels of DNA damage we recorded previously, for freshly collected and laboratory acclimated vent mussels (Dixon, Pruski, \& Dixon, 2004), and the level of the $64 \mathrm{kDa}$ isoform expressed in their tissues (Fig. 7), although the low, albeit significant Spearman correlation coefficient $(r s=0.70, P>0.05)$, requires further examination with a larger number of specimens.

\section{Discussion}

The hydrothermal vent environment is considered in human terms to be one of the most hostile environments on the planet. Apart from the elevated temperature and pressure, vent organisms are exposed to high levels of potentially toxic heavy metals, sulphide and radionuclides, in a harsh environment that favours oxidative stress (see Pruski \& Dixon, 2003 for further discussion). While there is a significant body of evidence which shows that animal cells have evolved a variety of elaborate defence and repair mechanisms to protect them against the genotoxic effects of natural environmental stressors, the molecular chaperone system is thought to be an important defence mechanism against proteotoxic injury at the cellular level across the full phylogenetic spectrum, from bacteria to man (Ohtsuka \& Hata, 2000). Hence, any variable that perturbs protein homeostasis is likely to trigger the induction of stress proteins (Morimoto, \& Santoro, 1998). The present study describes the HSP characteristics of the hydrothermal vent mussel B. azoricus, a dominant member of the mid-Atlantic Ridge vent fauna, when collected from a range of vent sites displaying different environmental conditions, and when collected using two different recovery methods, ROV and acoustically operated cages. 


\subsection{Levels of HSP70 in Mytilus edulis}

The edible mussel Mytilus edulis was selected for comparison in this study because it is a close relative of B. azoricus. In fact, vent species such as B. azoricus are believed to have had their evolutionary origins in shallow-water at a time in the geological past when venting was more widespread across the face of the planet (Jacobs \& Lindberg, 1998). This is supported by the discovery that the present day coastal marine fauna shares a number of important characteristics in common with vent species, which points to pre-adaptation having played an important role during vent colonisation in the geological past. It should be noted that both environments are typified by marked fluctuations in temperature, salinity and increased contaminant burdens. Reflecting this close evolutionary relationship, B. azoricus shares a number of fundamental biological features in common with $M$. edulis regarding life-history strategy, toxicant defence, tissue and DNA repair, and thermal resistance (Le Pennec, \& Beninger, 2000; Hardivillier, Leignel, Denis, Uguen, Cosson, \& Laulier, 2004; Pruski \& Dixon, 2003; Dixon et al., in press). Apart from the obvious differences in the levels of sulphide and methane in the water column, the main environmental feature that distinguishes the present-day deep-sea vent environment from conditions in the intertidal zone is the greatly increased hydrostatic pressure.

Our results showed that two proteins related to the human inducible stress protein HSP72 appeared to be inducible in M. edulis in response to heat shock ( 15 to $28^{\circ} \mathrm{C}$ ) and exposure to a sublethal dose of cadmium (Fig. 1). These results are in agreement with previous investigations on the expression of HSP70 in this species (Chapple, Smerdon, \& Hawkins, 1997; Radlowska, \& Pempkowiak, 2002; Sanders, Martin, Howe, Nelson, Hegre, \& Phelps, 1994) and confirmed that the primary antibody chosen for this study was able to detect what may have been a mixture of constitutive and inducible HSP70 isoforms in a bivalve species closely related to B. azoricus. In contrast, for the rat, this antibody has been reported as recognising only the inducible form of HSP70, termed HSP72 (Yukako, Masato, Ken , Michiyo \& Hiroshi, 2003), which emphasises an urgent need for further comparative studies focusing on a range of marine invertebrates. 


\subsection{Levels of HSP70 in Bathymodiolus azoricus}

Here, we present the first evidence for the expression and induction of stress proteins belonging to the HSP70 family in a dominant member of the Atlantic hydrothermal-vent fauna. Moreover, we detected tissue-specific differences in the expression patterns of the HSP70 proteins. Whilst only one immunoreactive band, a constitutive HSP70, was detected in extracts made from the mantle tissue $(\mathrm{Mr} \sim 71 \mathrm{kDa})$, which serves both as an energy storage and reproductive tissue at different times of the year (Dixon et al., in press), two additional bands reacted with the HSP72 antibody in extracts made from the gills (Fig. 2). We also showed that the lighter of these two proteins (Mr 64 $\mathrm{kDa}$ ) was stress-inducible, and may correspond to the expression of another gene product of the HSP70 family, as previously observed in M. edulis by Sanders (1993).

Variations in the levels of HSP70 isoforms among tissues have already been reported in M. edulis in response to heat and copper exposure (Chapple, Smerdon, \& Hawkins, 1997; Sanders, Martin, Howe, Nelson, Hegre, \& Phelps, 1994). These differences were explained in terms of differences in tissue vulnerability to a specific stressor and/or physiological function (Chapple, Smerdon, \& Hawkins, 1997; Sanders, Martin, Howe, Nelson, Hegre, \& Phelps, 1994). The increased levels we observed for stress protein in the gills of vent mussels could therefore be explained by the fact that this tissue experiences greater exposure to water movement, whereas the mantle is by comparison, relatively protected within the shell. In support of this, reduced heavy metal concentrations have been found in the mantle tissues of B. azoricus from the three sites (Bebiano, Company, Searfim, Camus, Cosson, \& Fiala-Médioni, 2005). Furthermore, the chemosynthetic autotrophic symbionts that live within the gill cells of B. azoricus represent a potential additional cause of stress through the production of oxygen and sulphur free radicals (Tapley, Buettner, \& Shick, 1999), which may affect the gills in particular. In this respect, it should be mentioned that stress proteins related to

the mammal HSP70 family (DnaK) have also been found in bacteria (De Maio, 1995), but it is unlikely that stress proteins from the bacterial endosymbionts within B. azoricus would cross-react 
with the commercially produced HSP72 antibody used in the present study, since this antibody was raised specifically against eukaryotic HSP70 (Stressgen Corp).

Bathymodiolus azoricus was collected from three sites characterised by different contaminant loads (Douville et al., 1999; Sarradin et al., 1999) and different bathymetric depths (Menez Gwen: 840m; Lucky Strike: 1700m; Rainbow: 2400m). Based on the relationship between the chemistry of vent fluid and depth, the more harmful conditions were expected to be found at the deeper, Rainbow site, whereas in comparison the level of overall toxicity at the relatively shallow Menez Gwen site was expected to be low, due to the phenomenon of low-pressure induced phase separation (Charlou et al., 2000). Results of two studies on heavy metal tissue burdens in mussels from the three sites are consistent with this expectation, and was consistent with animals from the relatively shallow Menez Gwen site having been shown to contain lower levels of heavy metals in their soft tissues (Rousse, Boulègue, Cosson, \& Fiala-Médioni, 1998; Bebiano, Company, Searfim, Camus, Cosson, \& FialaMédioni, 2005). In the present study, the low expression of the $64 \mathrm{kDa}$ isoforms we recorded for mussels from the Menez Gwen vent site was consistent with these earlier results and expectations, and may reflect their reduced exposure to toxic vent fluids. In contrast, the level of expression of the $71 \mathrm{kDa}$ isoform was roughly constant in specimens from all three sites (Figure 3), which strongly supports that this protein is a constitutive form of HSP70. However, the additional complication of decompression stress during animal collection had also to be considered.

\subsection{Effects of collection and laboratory acclimation on Bathymodiolus azoricus}

A major complicating factor when dealing with deep-sea organisms in an experimental context is the obligate stress imposed by the collection process, and the potential for sub-cellular damage resulting from decompression (Dixon, Pruski and Dixon, 2004). In the absence of isobaric collection methods, we compared two different collection systems (i.e. ROV and retrievable cages). Since cage collection took significantly less time than was typical for ROV collections (a few tens of minutes compared to hours), it was hoped that in this way we would be able to dissociate the 
stresses linked to decompression stress from those emanating from extended exposure to temperature change, anoxia etc. This expectation was borne out by the significantly higher levels of HSP70 isoforms, which are indicative of protein damage, we found in mussels that were collected using the ROV, compared to those recovered using the cages. Furthermore, we reported earlier an increased level of DNA strand breakage in the same specimens (Pruski \& Dixon, 2003). These results confirm that the extended decompression and handling times experienced during ROV collection can be a major cause of stress for deep-sea organisms.

In contrast, the retrievable cages (Dixon et al., 2001) provided a much less stressful collection method, as indicated by the lower levels of HSP70 expression and DNA strand breakage (Pruski \& Dixon, 2003). This striking difference can be attributed to the fact that animal recovery using the cages was achieved in only 20 - 30min (from 840m), while from the deeper sites, using the ROV, animal recovery took in some cases up to $15 \mathrm{~h}$ (Pruski \& Dixon, personal observation). During this extended ROV collection experience, vent mussels were subjected to a combination of physical disturbance and physiological stress (vibration and exposure to the warm water overlying the thermocline), plus possible anoxia due to their shells having remained closed for an extended period (Famme \& Knudsen, 1983), all of which could lead to increased levels of HSP70 expression.

It is worth mentioning too that since ROV collection appears to be a major cause of stress in vent mussels, the response of the organisms to the collection experience could easily mask any siterelated differences in the patterns of expression of HSP70 (Fig. 2).

\subsection{Sub cellular localisation of HSP70 in Bathymodiolus azoricus}

The sub cellular localisation results for HSP70 in the gills of B. azoricus revealed that the 71 $\mathrm{kDa}$ and $64 \mathrm{kDa}$ proteins were expressed in the cytoplasm both of acclimated (1 week) and freshly collected mussels. The $71 \mathrm{kDa}$ protein was also detected in the cell nuclei of thermally stressed 
animals. This was not wholly unexpected since HSP70s are cytoplasmic proteins that are capable of transiently migrating to the nucleus under conditions of increased stress (Welch \& Feramisco, 1984), the principal signal being the presence of unfolded proteins. What was unexpected however was the retention of the $71 \mathrm{kDa}$ protein in the cell nuclei of mussels that had been acclimated to laboratory aquarium conditions for 7 days.

Two hypotheses can be proposed to explain this finding: First, the laboratory kept mussels remained stressed. This was however somewhat surprising since the sea water was devoid of any of the toxicants naturally present in the hydrothermal habitats (e.g. heavy metals, radionuclides, sulphide...), and a constant low temperature was maintained throughout the acclimation period. Furthermore, considering the transitory nature of the HSP70 response (Abe et al., 1995), any stress protein induced by the collection process should have been eliminated from the nucleus within 7 days. It should be noted that vent mussels from the same Menez Gwen site have been maintained successfully under similar laboratory aquarium conditions for more than 12 months, where their condition was considered good based on measurements of shell growth and endosymbiont condition criteria (P. Dando, pers. com.). Moreover, our contemporaneous DNA damage study (Dixon, Pruski \& Dixon, 2004) showed a marked recovery in condition (as measured by DNA repair) after 7 days. This leads to the second explanation which is that this constitutive HSP70 is normally present in the nuclei of B. azoricus gill cells under unstressed conditions. In which case, it could represent an adaptive response to the chronic stress conditions they experience throughout life in the deep-sea vent environment. In keeping with this explanation, the constitutive expression of HSP72i has been observed in the nuclei of unstressed rat muscle cells (Locke, Noble, \& Atkinson, 1991).

\subsection{Relationship between the levels of HSP70 and DNA strand breakage in gills of Bathymodiolus} azoricus

We observed a positive correlation between the intensity of the $64 \mathrm{kDa}$ band and the level of DNA strand breakage in B. azoricus gills, which indicates that stressed mussels suffer two different 
types of damage: DNA damage and injury involving the protein/cytosolic fraction. Several authors have reported a similar finding in vertebrates and invertebrates, under both laboratory and field conditions (Abe et al., 1995; Müller et al., 1998; Schröder et al., 2000), however how these two endpoints relate functionally remains unclear. Recent studies have shown that heat shock enhances DNA repair (Bellmann, Wenz, Radons, Burkart, Kleemann, \& Kolb, 1995; Burkart, et al., 2000) and Kenny and co-workers have recently demonstrated that HSP70 binds to the human apurinic/apyrimidinic endonuclease, an enzyme involved in base excision repair (Kenny et al., 2001). Since, the $64 \mathrm{kDa}$ isoform was not detected in the nucleus, its direct involvement in DNA repair is not possible. However, there remains the possibility that the expression of this isoform could be correlated with another stress protein involved in DNA repair.

\section{Conclusion}

A major complication when working on deep-sea species in an experimental context is the potential for reduced quality/health following collection. This study confirms our previous finding which showed vent organisms were particularly stressed during ROV collection (for review see Dixon, Pruski, \& Dixon, 2004). However, this stress reaction seems to result mainly from the handling and storage of specimens rather than the effects of decompression per se. Bathymodiolus azoricus is one of the dominant species of the MAR (mid Atlantic ridge) hydrothermal vent sites and is naturally exposed to high levels of toxic compounds such as heavy metals, radionuclides, reduced sulphur compounds and oxygen free radicals. Thus, the high levels of HSP70 we found in the tissues, together with the expression of at least one constitutive HSP70 in the cell nucleus, points to a crucial role played by these stress proteins throughout the life of the vent mussel in its naturally hostile deep-sea environment.

\section{Acknowledgements}

We wish to express our grateful thanks to the following people and organisations for their help and support during this study: Pierre Marie Sarradin (IFREMER) chief scientist during the ATOS cruise, the captain and crew of the R/V l'Atalante, the ROV Victor team, the captain and crew of 
the R/V Arquipelago, and the director and staff of IMAR DOP (Horta). This research was funded largely by the EU Framework Contract NEVK3-CT1999-00003 (VENTOX) and A.M.P. was supported by an EU Marie Curie Fellowship which was held at the National Oceanography Centre in Southampton. We are grateful to Dr M. Tedengren and two anonymous reviewers for constructive reviews. 


\section{References}

Abe, T., Konishi, T., Hirano, T., Kasai, H., Shimizu, K., Kashimura, M., \& Higashi, K. (1995).

Possible correlation between DNA damage induced by hydrogen peroxide and translocation of heat shock 70 protein into the nucleus. Biochemical and Biophysical Research Communications, 206, $548-555$.

Bellmann, K., Wenz, A., Radons, J., Burkart, V., Kleemann, R., \& Kolb, H. (1995). Heat shock induces resistance in rat pancreatic islet cells against nitric oxide, oxygen radicals and streptozotocin toxicity in vitro. The Journal of Clinical Investigations, 95, 2840-2845.

Bensaude, O., Pinto, M., Dubois, M.-F., Van Trung, N., \& Morange, M. (1990). In: Stress proteins, Chapter 8: Protein denaturation during heat shock and related stress (pp.88-99). Schlesinger, Santoro, Garaci (eds.), Springer-Verlab Berlin Heidelberg.

Bradley, B. P., Olsson, B., Brown, D. C., \& Tedengren, M. (1998). HSP70 levels in physiologically stressed Baltic sea mussels. Marine Environmental Research, 46, 397-400.

Burkart, V., Liu, H., Bellmann, K., Wissing, D., Jaattela, M., Cavallo, M. G., Pozzilli, P., Briviba, K., \& Kolb, H. (2000). Natural resistance of human beta cells toward nitric oxide is mediated by heat shock protein 70. The Journal of Biological Chemistry, 275, 19521-19528.

Chapple, J. P., Smerdon, G. R., \& Hawkins, A. J. S., (1997). Stress-70 protein induction in Mytilus edulis: Tissue-specific responses to elevated temperature reflect relative vulnerability and physiological functions. The Journal of Experimental Marine Biology \& Ecology, 217, 225-235.

Charlou, J.L., Donval, J.P., Douville, E., Jean-Baptiste, P., Radford-Knoery, J., Fouquet, Y., Dapoigny, A., Stievenard, M. (2000). Compared geochemical signatures and the evolution of Menez Gwen $37^{\circ} 50 \mathrm{~N}$ and Lucky Strike $37^{\circ} 17 \mathrm{~N}$ hydrothermal fluids, south of the Azores Triple Junction on the Mid-Atlantic Ridge. Chemical Geology, 171, 49-75.

De Maio, A. (1995). The heat-shock response. New Horizons, 3, 198-207.

Desbruyères, D; Biscoito, M; Caprais, J-C; Colaco, A; Comtet, T; Crassous, P; Fouquet, Y; Khripounoff, A; Le Bris, N; Olu, K; Riso, R; Sarradin, P-M; Segonzac, M; Vangriesheim, A. 
(2001). Variations in deep-sea hydrothermal vent communities on the Mid-Atlantic Ridge near the Azores plateau. Deep-Sea Research Part I, 48, 1325-1346.

Dixon, D. R., Dando, P. R., Santos, R. S., Gwynn, J. P., \& the VENTOX consortium (2001). Retrievable cages open up new era in deep-sea vent research. InterRidge News, 10(2), 21-23.

Dixon, D. R., Pruski, A.. M., \& Dixon, L. R. J. (2004). The effects of hydrostatic pressure change on DNA integrity in the hydrothermal-vent mussel Bathymodiolus azoricus: implications for future deep-sea mutagenicity studies. Mutation Research, 552(1-2) : 235-246

Dixon, D.R., Lowe, D.M., Miller, P.I., Villemin, G., Colaço, A., Serrão-Santos, R., \& Dixon, L.R.J. (2006). Evidence for seasonal reproduction in the Atlantic vent mussel Bathymodiolus azoricus, and an apparent link to the timing of photosynthetic primary production. In press in Journal of the Marine Biological Association of the United Kingdom.

Douville, E., Charlou, J. L., Donval, J. P., Fouquet, Y., Oelkers, E. H., Jove Colon, C. F., Bienvenu, P., Prieur, D., \& Appriou, P. (1999). Trace metals in hot acidic fluids from a deep-sea hydrothermal system in an ultra-mafic environment: Rainbow vent field (36²'1'N, MAR). AMORES Azores MidOceanic Ridge Ecosystem Studies, Final detailed scientific report, Theme $N^{o} 2$ (2/2) Submersible geological and geochemical studies, Fouquet Y. ed.

Dyer, S., Brooks, L., Dickson, K. L., Sanders, B. M., \& Zimmermann, E. G. (1993). Synthesis and accumulation of stress proteins in tissues of arsenite-exposed fathead minnows (Pimephales promelas). Environmental Toxicology and Chemistry, 12, 913-924.

Jacobs, D. K., \& Lindberg, D. R. (1998). Oxygen and evolutionary patterns in the sea: onshore/offshore trends and recent recruitment of deep- sea faunas. Proceedings of the National Academy of Sciences of the U.S.A., 95, 9396-9401.

Le Pennec, M., \& Beninger, P.G. (2000). Reproductive characteristics and strategies of reducingsystem bivalves. Comparative Biochemistry and Physiology Part A, 126, 1-16.

Famme, P., \& Knudsen, J. (1983) Transitory activation of metabolism, carbon dioxide production and release of dissolved organic carbon by the mussel Mytilus edulis L., following periods of selfinduced anaerobiosis. Marine Biological Letters, 4, 183-192. 
Fiala-Médioni, A., McKiness, Z. P., Dando, P., Cavanaugh, C., Robinson, R., Boulègue, J., Mariotti, A. \& Alayse-Danet, A.M. (2002). Ultrastructural, biochemical, and immunological characterization of two populations of a new species of mytilid mussel, Bathymodiolus azoricus, from the Mid-Atlantic Ridge: Evidence for a dual symbiosis. Marine Biology, 141, 1035 - 1043.

Fiala-Médioni, A.,Thiebaut, E., Castrec-Rouelle, M., Martins, I., Cosson, R., Company, R., Laullier, M., Bebianno, M. J., \& Sarradin, P. M. Spatial variability of metal bioaccumulation in the Azores hydrothermal vent mussel Bathymodiolus azoricus. Submitted to Marine Pollution.

Fink, A. L. (1999). Chaperone-Mediated Protein Folding. Physiological Reviews, 79, 425-449.

Kenny, M. K., Mendez, F., Sandigursky, M., Kureekattil, R. P., Goldman, J. D., Franklin, W. A., \& Bases, R. (2001). Heat Shock Protein 70 binds to human apurinic/apyrimidinic endonuclease and stimulates endonuclease activity at abasic sites. The Journal of Biological Chemistry, 276, 95329536.

Laemmli, U. K. (1970). Cleavage of structural proteins during the assembly of the head of bacteriophage T4. Nature, 227, 680-685.

Hardivillier, Y., Leignel, V., Denis, F., Uguen, G., Cosson, R., \& Laulier, M. Do organisms living around hydrothermal vent sites contain specific metallothioneins? The case of the genus Bathymodiolus (Bivalvia, Mytilidae). (2004). Comparative Biochemestry and Physiology Part C, $139,111-118$.

Lagerspetz, K. Y. H., Korhonen, I. A., \& Tuska, A. J. (1995). Heat shock response and thermal acclimation effects in the gills of Anodonta cygnea: ciliary activity, stress proteins and membrane fluidity. Journal of Thermal Biology, 20, 43-48.

Locke, M., Noble, E. G., \& Atkinson, B. G. (1991). Inducible isoform of HSP70 is constitutively expressed in a muscle fiber type specific pattern. American Journal of Physiology, 26, 774-779

Morimoto, R.I., \& Santoro, M.G. (1998). Stress-inducible responses and heat shock proteins: new pharmacologic targets for cytoprotection. Nature Biotechnology, 16(9):833-838.

Mosholder, R. S., Josephson, R. V., \& Phleger, C. F. (1979). Swimbladder membrane protein of an abyssal fish, Coryphaenoides acrolepis. Physiological Chemistry and Physics, 11, 37-47 
Müller, W. E. G., Batel, R., Lacorn, M., Steinhart, H., Simat, T., Lauenroth, S., Hassanein, H. M. A., \& Schröder, H. C. (1998). Accumulation of cadmium and zinc in the marine sponge Suberites domuncula and its potential consequences on single-strand breaks and on expression of heat-shock protein: a natural field study. Marine Ecology Progress Series, 167, 127-135.

Nover, L. (ed.) (1991). The heat shock response. CRC Press, Boca Raton (Fd.).

Ohtsuka, K., \& Hata, M. (2000). Molecular chaperone function of mammalian Hsp70 and Hsp40 a review. International Journal of Hyperthermia, 16(3), 231-245.

Pruski, A.M., \& Dixon, D.R. (2002). Effects of cadmium on nuclear integrity and DNA repair efficiency in the gill cells of Mytilus edulis L. Aquatic Toxicology, 56(5), 127-137.

Pruski, A. M., \& Dixon, D. R. (2003). Toxic vents and DNA damage: first evidence from a naturally contaminated deep-sea environment. Aquatic Toxicology, 64(1), 1-13.

Radlowska, M., \& Pempkowiak, J. (2002). Stress-70 as indicator of heavy metals accumulation in blue mussel Mytilus edulis. Environment International, 27, 605-608

Rousse, N., Boulègue, J., Cosson, R. P., \& Fiala-Médioni, A., 1998. Bioaccumulation des métaux chez le mytilidae hydrothermal Bathymodiolus sp. de la ride médio-Atlantique. Oceanologica Acta, 21, 597-607.

Sanders, B. M. (1993). Stress proteins in aquatic organisms: an environmental perspectives. Critical Reviews in Toxicology, 23, 49-75.

Sanders, B. M., Martin, L. S., Howe, S. R., Nelson, W. G., Hegre, E. S., \& Phelps, D. K. (1994). Tissue-specific differences in accumulation of stress proteins in Mytilus edulis exposed to a range of copper concentrations. Toxicology \& Applied Pharmacology, 125, 206-213.

Sarradin, P. M., Caprais, J. C., Riso, C., Kerouel, R., \& Aminot, A. (1999). Chemical environment of the hydrothermal mussel communities in the Lucky Strike and Menez Gwen vent fields, Mid Atlantic Ridge. Les Cahiers de Biologie Marine, 40, 93-104.

Sarradin, P. M., Desbruyères, D., Dixon, D. R., Almeida, A., Caprais, J. C., Colaço, A., Company, R., Cosson, R., Cueff, V., Dando, P. R., Etoubleau, J., Fiala-Médioni, A., Gaill, F., Godfroy, A., Gwynn, J. P., Hourdez, S., Jollivet, D., Khripounoff, A., Lallier, F., Laulier, M., Le Bris, N., 
Martins, I., Mestre, N., Pruski, A. M., Rodier, P., Santos, R. S., Shillito, B., Zal, F., \& Zbinden, M. (2001). ATOS cruise R/V l'Atalante, ROV Victor, June $22^{\text {nd }}-$ July $21^{\text {st }} 2001$. InterRidge News, $10(2), 18-20$.

Schröder, H. C., Batel, R., Hassanein, H. M. A., Jenke, H.-St., Simat, T., Steinhart, H., \& Müller, W. E. G. (2000). Correlation between the level of the potential biomarker, heat-shock protein, and the occurrence of DNA damage in the dab, Limanda limanda: a field study in the North Sea and the English Channel. Marine Environmental Research, 49, 201-215.

Sim, D. L. C., \& Chow, V. T. K. (1999). The novel human HUEL (C4orf1) gene maps to chormosome 4p12-p13 and encodes a nuclear protein containing the nuclear receptor interaction motif. Genomics, 59, 224-233.

Tapley, D. W., Buettner, G. R., \& Shick, J. M. (1999). Free radicals and chemoluminescence as products of the spontaneous oxydation of sulfide in seawater, and their biological implications. The Biological Bulletin, 196, 52-56.

Tedengren, M., Olsson, B., Reimer, O., Brown, D. C., \& Bradley, B. P. (1999). Heat pretreatment increases cadmium resistance and HSP 70 levels in Baltic sea mussels. Aquatic Toxicology, 48, 112.

Trask, J. L., \& Van Dover, C. L. (1999). Site-specific and ontogenic variations in nutrition of mussels (Bathymodiolus sp.) from the Lucky Strike hydrothermal vent field, Mid-Atlantic Ridge. Limnology \& Oceanography, 44, 334-343.

Verbeke, P., Fonager, J., Clark, B. C., \& Rattan, S. I. S. (2001). Heat shock response and ageing: mechanisms and applications. Cell Biology International, 25, 845-857.

Welch, W.J., \& Feramisco, J. R. (1984). Nuclear and Nucleolar Localization of the 72,000-dalton Heat ShockProtein in Heat-shocked Mammalian Cells. Journal of Biological Chemistry, 259, 45014513.

Wickner, S., Maurizi, M. R., \& Gottesman, S. (1999). Posttranslational quality control: folding, refolding and degrading proteins. Science, 286, 1888-1893. 
Figure caption

Figure 1: Western blot analysis of stress-70 proteins in gill and mantle tissues of Mytilus edulis.

The positions of prestained precision protein standards (Bio-Rad) are indicated in $\mathrm{kDa}$ on the left.

Lanes 1 and 2: control mussel; Lanes 3 and 4: mussel exposed to heat shock; Lanes 5 and 6, mussel exposed to cadmium.

Figure 2: Western blot analysis of stress-70 proteins in gill and mantle tissues from three $B$. azoricus collected from three vent sites on the MAR and one Mytilus edulis.

The positions of prestained precision protein standards (Bio-Rad) are indicated in $\mathrm{kDa}$ on the left.

Figure 3: Mean intensities (relative optical density) of the 64, 71 and $76 \mathrm{kDa}$ bands in (A) gill and (B) mantle tissues of B. azoricus collected from 3 vent sites on the MAR.

For western blotting, equivalent amounts of protein (12 $\mu \mathrm{g}$ per sample) were electrophoresed in each lane. Scanning densitometry was performed on western blots developed with the Bio-Rad enhanced alkaline phosphatase assay. Densities of Hsp70 bands were calculated with Quantity One software and standardized to an internal standard (a single gill extract sample from Mytilus edulis run on each gel). Values are means \pm 1.S.D., $N=3$. Black bars: $76 \mathrm{kDa}$ isoform, white bars: $71 \mathrm{kDa}$ isoform, grey bars: $64 \mathrm{kDa}$ isoform.

Figure 4: Representative Western blot comparing levels of stress-70 protein expression in gill tissues of freshly collected and laboratory-acclimated B. azoricus.

The positions of prestained precision protein standards (Bio-Rad) are indicated in $\mathrm{kDa}$ on the left.

Figure 5: Mean intensities (relative optical density) of the 64 and $71 \mathrm{kDa}$ HSP 70 bands in gills of the hydrothermal vent mussel Bathymodiolus azoricus collected using either the ROV Victor or the 
retrievable cages. Mussels were either dissected immediately after collection ("freshly collected") or exposed to a mild heat shock (ROV + HS) or acclimated to laboratory conditions for 1 week in artificial sea water (Cage +1 week ASW). White bars: $71 \mathrm{kDa}$ isoform and black bars: $64 \mathrm{kDa}$ isoform. Values are expressed as mean $+1 \mathrm{SD}, N=4$.

Figure 6: Western blot analysis of representative whole-cell lysates and subcellular fractions of field collected and laboratory acclimated specimen of the vent mussel Bathymodiolus azoricus. The positions of prestained precision protein standards (Bio-Rad) are indicated in kDa on the left.

Figure 7: Relationship between the level of DNA strand-breakage as measured with single cell gel electrophoresis (\% Tail DNA: Comet assay) and the intensity (relative optical density) of the 64 $\mathrm{kDa}$ isoform in freshly collected and laboratory acclimated mussels from the Menez Gwen site.

The non-parametric Spearman rank-order correlation coefficient confirms that the two variables are significantly correlated $(r s=0.70 ; P<0.05, N=10)$. 
Figure 1

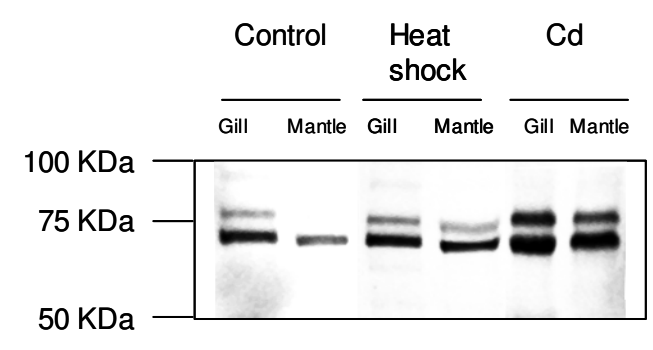


Figure 2

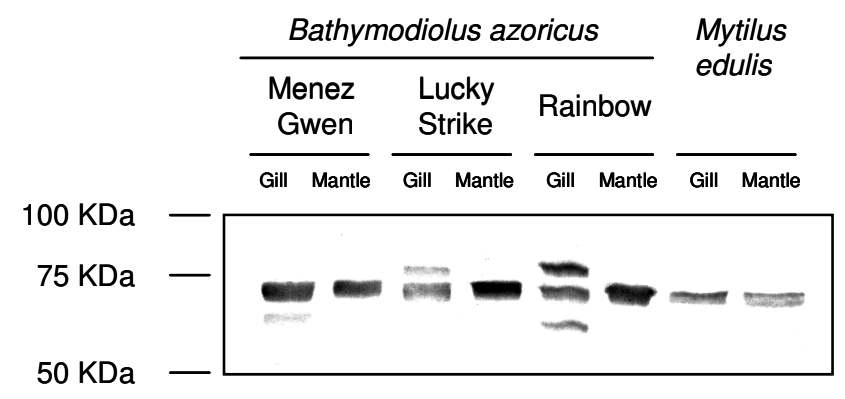


Figure 3
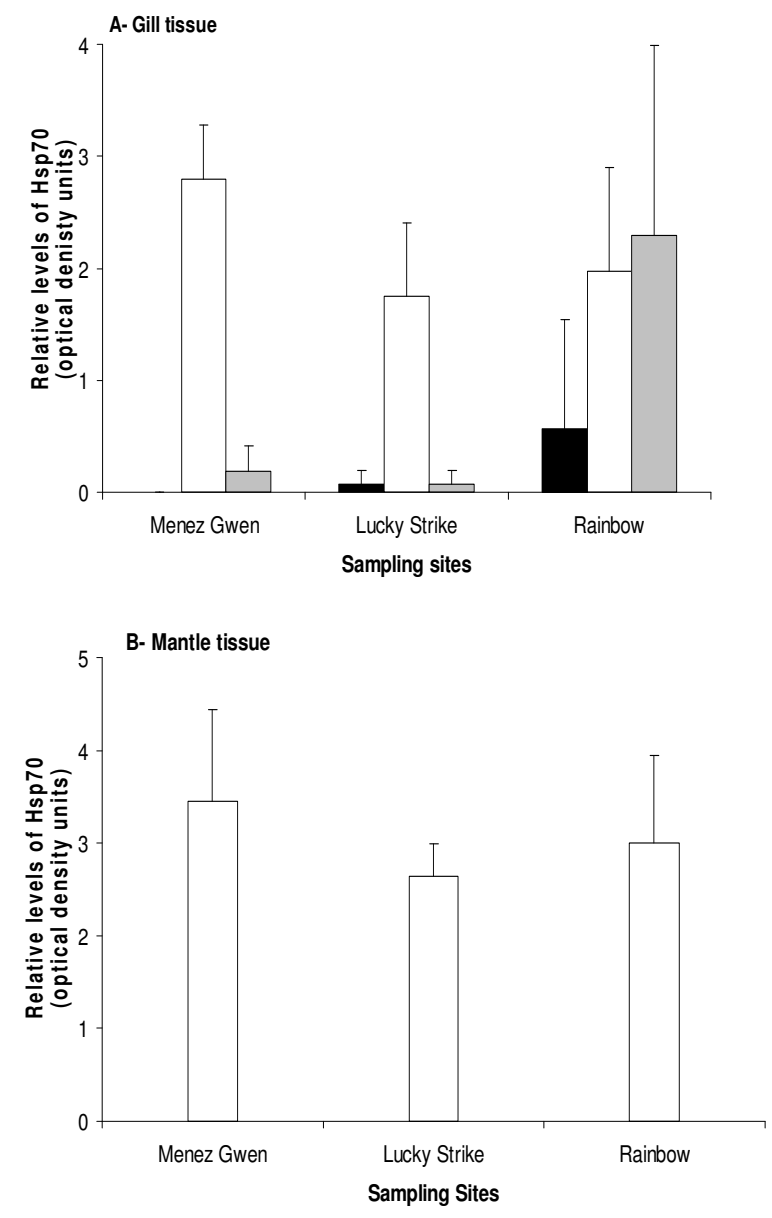
Figure 4

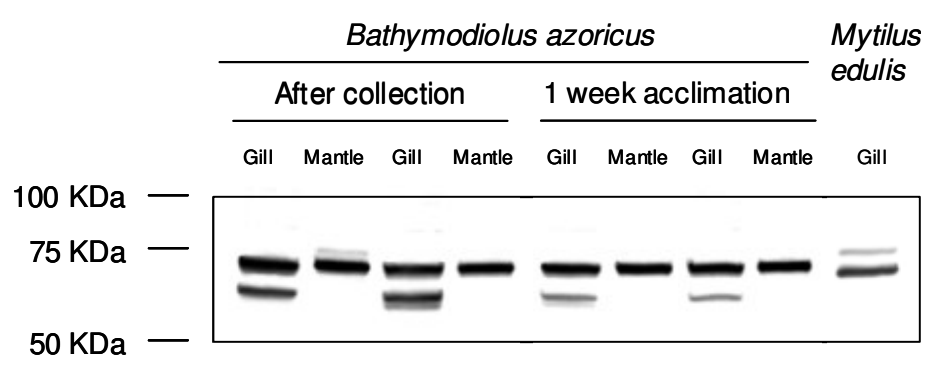


Figure 5

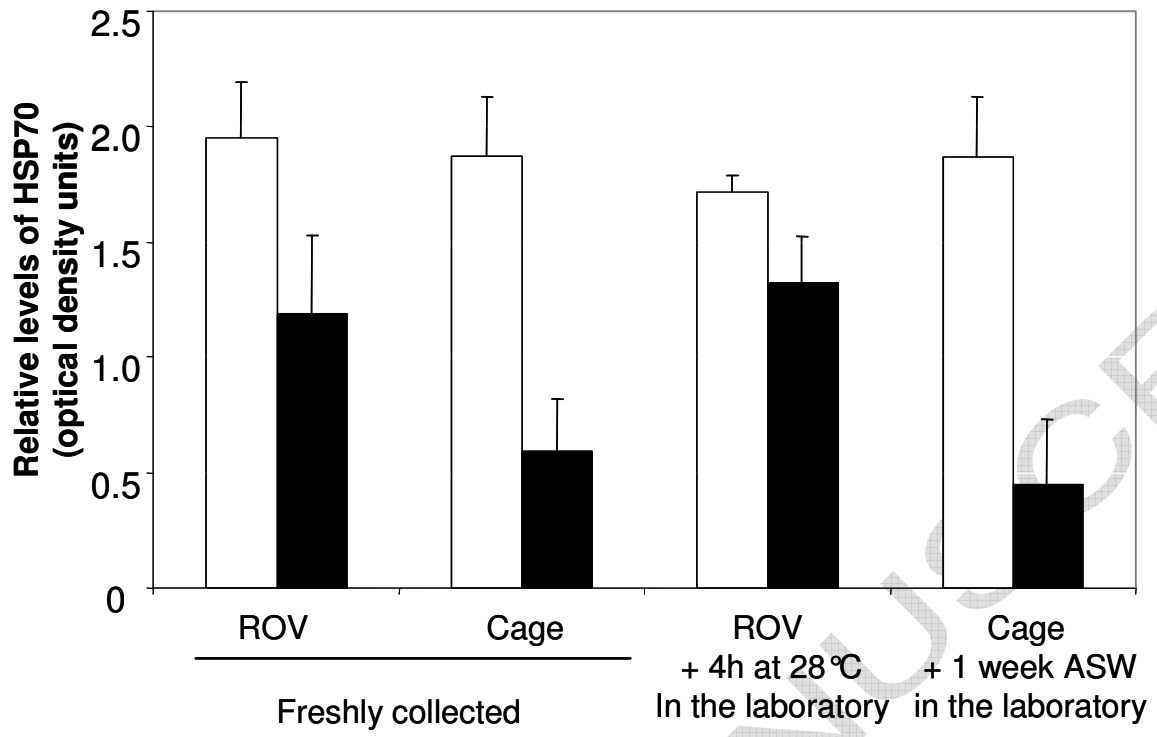


Figure 6

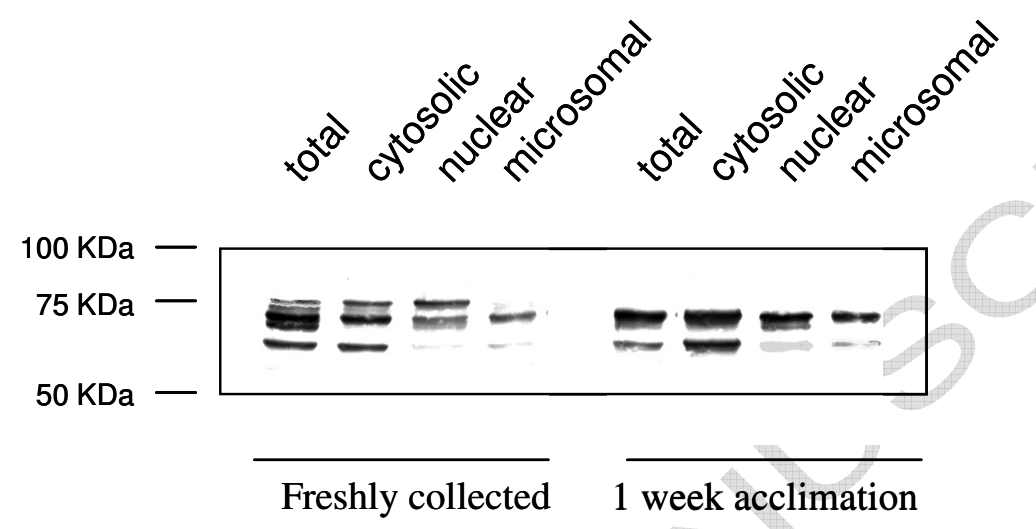


Figure 7

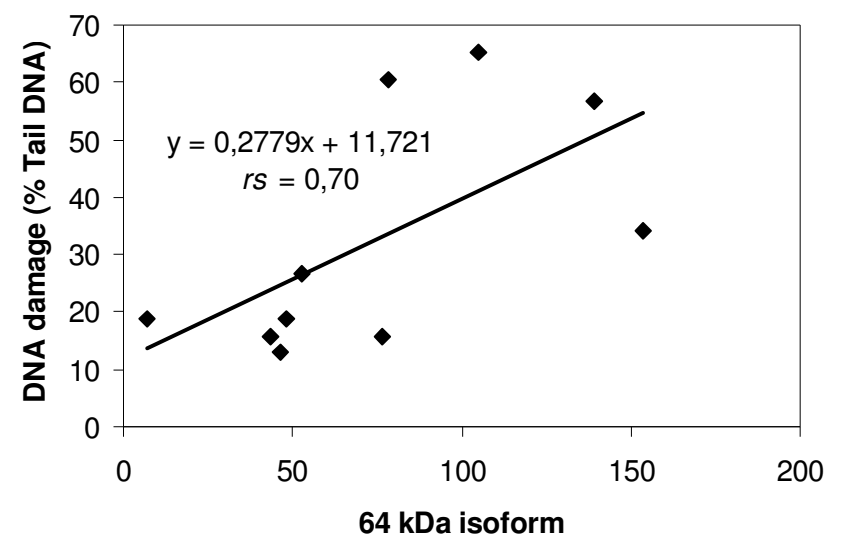

